\title{
The 100th Anniversary of the Foundation of the CPC Conference Content Profound Understanding and Enlightenment
}

\author{
Zuomin Yang \\ School of Marxism, Qingdao University of Science and Technology, Qingdao, China \\ Email: zmy202006@gmail.com
}

How to cite this paper: Yang, Z.M. (2022) The 100th Anniversary of the Foundation of the CPC Conference Content Profound Understanding and Enlightenment. Open Access Library Journal, 9: e8272. https://doi.org/10.4236/oalib.1108272

Received: December 12, 2021

Accepted: January 1, 2022

Published: January 4, 2022

Copyright $\odot 2022$ by author(s) and Open Access Library Inc.

This work is licensed under the Creative Commons Attribution International License (CC BY 4.0).

http://creativecommons.org/licenses/by/4.0/

\section{(c) (i) Open Access}

\begin{abstract}
Centennial CPC, centennial accumulation, July 1, 2021, at 8 a.m., the Chinese capital Beijing Tian'anmen Square solemnly held the centennial congress of the founding of the CPC. Reviewed the glorious course of the 100th anniversary of the founding of the CPC, standing on the second centennial starting point, for the future development of our country made requirements and expectations. This article based the speech content on profound understanding and learning made self-cognition and revelation. In a century of struggle, the CPC will always be the helmsman of the Chinese nation.
\end{abstract}

\section{Subject Areas}

Politics

\section{Keywords}

Communist Party of China, National Rejuvenation, 100th Anniversary of the CPC Establishment

\section{Introduction}

Morning of July 1, 2021, the Chinese president Jinping Xi solemnly declared: "After the founding of the CPC, the Chinese people of all ethnic groups continue to struggle, we achieved the first Centenary Goal, build a well-off society in an all-round way on Chinese land, historic to solve the problem of absolute poverty, we are moving energetically toward the second centenary goal of building China into a great modern socialist country in all areas".

Based on the speech delivered at the Centennial Congress of the Foundation of the CPC, the general contents of this article are as follows. 
1) Factors of decline before the founding of new China;

2) The CPC has forged ahead with the people in the past 100 years;

3) To realize the great rejuvenation of the Chinese nation, the Chinese mainland and Taiwan must integrate.

The following contents are the details of my thoughts and enlightenment.

\section{Understanding and Enlightenment}

\subsection{Factors of Decline before the Founding of New China}

Before the foundations of new China was a kind of untold suffering, social turbulent, under the circumstances of people chronic poverty, hunger. In the aggregate, it was caused primarily by two factors. The first factor is external factors by foreign imperialist oppression; the second factor is affected by the feudal ideas colluding with foreign and domestic. External factors have the invasion of sovereignty, territory, airspace, cultural infiltration, property, and material. Under the erosion of foreign imperialism, China has gradually become a semi-colonial and semi-feudal society from the world's first power. Internal factors main include two aspects: the first aspect is from Chinese national to the late Qing dynasty, China has experienced more than 5000 years history, has a long history of civilization has been in has under the rule of the feudal dynasty, the minds of ordinary Chinese have formed a kind of feudal ideas, especially after the opium war in 1840, the Qing government ignorance, complacency, corruption, incompetence, and the isolation of the country led to the ceding of land by reparations, leaving the Chinese people, especially the average person, in distress. The second aspect is the corruption and incompetence of the old National government, which colluded with foreign forces, prevailed in bureaucracy and capitalism, and oppressed the people in general, causing the vast number of poor Chinese people to be displaced from place to place. The people long for stability, harmony, and liberation from evil.

\subsection{Seek Happiness for the People and Rejuvenation for the Chinese Nation}

On July 23, 1921, when the nation was in danger, the birth of the CPC completely changed the direction of China's future development, brought new hope and vitality to the people and the whole country, and became the most principal "savior" in the hearts of Chinese people [1].

Since the foundation of the CPC has always taken saving the country and people as its mission and responsibility. One hundred years ago, the CPC let China change from a poor, weak, hungry, and cold country to today's well-off society with all aspects and eradication of poverty in China. It is an unprecedented great event and achievement of supreme glory.

The original mission of the CPC is to seek happiness for the Chinese people and rejuvenation for the Chinese nation [2]. To seek happiness for the people means that the Chinese people can live the life of maximum satisfaction, con- 
tentment, and dignity. The rejuvenation of the Chinese nation implies that China's 56 ethnic groups will enjoy a more dignified life. China is a large developing country with a population of over 1.4 billion. China's politics, economy, culture, science, technology, and military are at an advanced international level, at the forefront of the world's powers.

Over the past 100 years, the CPC has always stood with the people, united and led the people of 56 ethnic groups in arduous struggle, fearlessly sacrificed, and bravely creation, and embarked on an unprecedented path that truly suits the Chinese people. Not only the honor of the Chinese people but also the pride of the sons and daughters of China.

\subsection{The Fruits of History Belong to the People, and the People Are National Heroes}

In the early days, the CPC put the people at the core. It always stood with the Chinese people and the masses of the people. The Chinese people are the masters of China, are the pioneers of the progress of human civilization, and the lifeblood of the CPC. The 19th National Congress of the CPC established adherence to the people as the critical center [3]. Without the Chinese people, there would be no Party. Without the Party, there would be no happy life of the Chinese people today. The people are the great creators in the theme of history, the real backbone of the nation, and the heroes of China. The CPC is closely bound to the people, and the Chinese people will surely accomplish the great cause of national rejuvenation.

\subsection{Uphold the Leadership of the CPC}

One hundred years after foundation with the CPC from just over 50 members to nowadays has more than 95 million members [4]. The CPC members are composed of the people, and the people have chosen the CPC, which fully reflects the "root feeling" and necessity of the CPC and people and the importance of the CPC in people's minds. The CPC has always taken the people as the inexhaustible driving force for governing the nation. United and led the Chinese people in their untiringly struggle for a better life for freedom and democracy, which dared to sweep away evil forces that are not conducive to the people. The CPC has devoted itself to the people. History has proved that implementing the capitalist system in China is not in line with China's national conditions. The capitalist system represented by the western countries is not feasible in China. Only Marxism-Leninism is suitable for China's development, and the integration of Marxism and China must be continuously promoted [5]. Marxism originated in the Soviet Union and was the practice in China. Only by integrating Marxism into China's 5000-year civilized society. It plays a better role and develops a strong country in China. The uniqueness of socialism in China is the derivative of the interaction between Marxism and China. It's the concretization of Marxism and the reality and essence of China, which is one of the quintessence of Marxism in China. We must adhere to and develop socialism with Chinese cha- 
racteristics. At the same time, we must adhere to Marxism-Leninism, Mao Zedong Thought, Deng Xiaoping Theory, the Important Thought of Three Represents, the Scientific Outlook on Development, and Xi Jinping's Thought on Socialism with Chinese Characteristics for a New Era.

Upholding and developing socialism with Chinese characteristics cannot be ensured without a strong army. Founded on August 1, 1927, the PLA has experienced the period of national Revolution, The War of Resistance against Japanese Aggression, the War of Liberation, and the New China. The HIGHEST military organ of the PLA is the Central Military Commission (CMC), which is composed of the Army, navy, air Force, Rocket Force, Strategic Support Force, and Joint Logistic Support Force. The PLA fears no sacrifice for national independence and liberation. For China's peace and tranquility, shoulder the historical responsibility of defending the country. China's population has grown from 400 million to 1.4 billion, people from the modern times when people were trampled and starved to the new era of socialism with Chinese characteristics, a strong military is indispensable for safeguarding sovereignty and territorial integrity and the interests of the people. National defense and the armed forces are an "iron wall" to defend national interests, and we must accelerate their modernization.

The people's army guards the country's sovereignty, territory, and territorial waters and airspace are complete. The guards are the interests of the masses of the people and nation, must improve the level of the people's army combat capability and combat, strengthen intelligence, modern weapons equipment research and development, and application, to guard the state peace and practice the socialist core values. The Chinese nation is a peace-loving nation and pursues the values and ideals of harmony between man and nature. The excellent Chinese civilization of more than 5000 years has a long and continuous history, which it cannot divide from the Chinese people's ideals of peace, amity, and harmony. The CPC is with the people of 56 ethnic groups in China. They have inherited and carried forward its fine traditions, upheld the concept of peace, harmony, and amity, and established close ties with other countries in the world. Thus it promotes world progress and development and contributes to world peace. Under the leadership of the CPC, the Chinese government grasps the concept of peace, development, and cooperation with a win-win situation. The world's peace-loving countries promote the progress and development of the whole world with them. To build the architecture of human fate, "One Belt and One Road" put forward by the CPC central construction measures has attracted worldwide attention, for world peace and development has made an indelible contribution to the world. The Chinese nation is strong. The Chinese people are united, are peace-loving, advocating justice. The 5000-year Chinese civilization proves that any foreign force, any barriers or hardship in the long history, cannot overwhelm the Chinese people and the Chinese nation. The Communist Party of China is the guiding light on the road of Chinese civilization, guiding the Chinese nationality and people to a more glorious distance. 


\subsection{The Principle of "One Country, Two Systems" Is Correct}

Hongkongers and Macanese are both members of the Chinese nation and sons and daughters of the Chinese country. They are also members of the great rejuvenation of China. Hong Kong and Macao region is the window of China with the world. Only China inland and Hong Kong and Macao region tightly together, the people of Hong Kong and Macao people with Chinese people, under the leadership of the CPC, strengthen the Chinese concentric and unity, and the Chinese nation is bound to accelerate the process of realizing the great rejuvenation of the Chinese nation's grand. Hong Kong is China's Hong Kong, and Macao is China's Macao. The achievement of Hong Kong and Macao have made since their return more than 20 years ago fully prove the superiority of the principle of one country, two systems. According to the one hundred great rejuvenation promotes overall plan, must be the accurate implementation of one country, two systems, Hong Kong people administer Hong Kong, Hands Macao, and a high degree of autonomy policy [6]. The central government has sovereignty over Hong Kong and Macao. The Special Administrative Region shall maintain the national security law system and execution mechanism and Safeguard state sovereignty, security, and development interests, maintaining the overall social stabilization and long-term prosperity and stabilization of Hong Kong and Macao.

\subsection{Taiwan Issue Must Be Solved}

Taiwan was an inalienable part of China's sovereignty, independence, and territorial integrity since ancient times. Taiwan all belongs to China. China into a rich and powerful modern country, the Mainland of China and Taiwan must be united. When the motherland is fully reunited, the Chinese people will be happier and more confident on the world stage. "1992 Consensus" is the basis for the reunification of the motherland, and Taiwan and the mainland must confirm that Taiwan and mainland China belong to the same country [7]. Both the People on the Chinese mainland and Taiwan belong to the sons and daughters of China. It is all the more important thing for us to work together with the people in Taiwan to realize the great cause of national rejuvenation.

\subsection{The Future Belongs to and Depends on the Younger}

The youth are the prerequisite for the prosperity of a country. The young people in the new era have active ideas, rich ideas, and responsibilities. The flourishing of a country depends on the youth, and the prosperity of a nation depends on the youth. Most of the CPC born on the red boat in Jiaxing are young people with outstrip ideas. They hold high the torch of Marxist thought and search hard for the future of national rejuvenation in the beacon age of national salvation. Advanced idea guides to action as well as correct action promote the development of ideas. The CPC can maintain its youth and vitality, relying on the Marxist youth generation. Youth is the source of the most advanced strength of 
the CPC, the wellhead of the ideas of exploring the prosperity of China, the source of the driving force for China's future development, and the vanguard force to realize the national rejuvenation.

The success or failure of a country depends on its youth. Generation after generation of Chinese people overthrew the old era, founded the new China to liberate themselves from the oppressive former rimes. It is an epoch-making event. From New China up to now, a generation of promising youth is to link past and future, one after another, for the country for the people's construction cause silently dedication, only for the national rejuvenation, the country map prosperity. The development of the motherland depends on youth. The teenager is the most solid backing and power of the development of the homeland.

As a new era, under the shine of the CPC of the younger generation, we should inherit preciously to taking history as a mirror. Always bearing load, firmly establish the socialist values, our best serve country, serve the society, serve the people. Seize the day and live it to the fullest, to realize the great rejuvenation of the Chinese nation as our responsibility, becoming a modern power in the process of the Rising Waves.

\section{Discussion}

This article is my profound understanding and reflection based on the speech delivered at the 100th anniversary of the founding of the CPC. It does not represent the views of others and has certain limitations. There were a lot of explains about the speech marking the 100th anniversary of the foundation of the CPC. Over the past 100 years, the CPC has united and led the Chinese people of all ethnic groups into a new era of socialism with Chinese characteristics. The CPC has exerted a positive influence on Chinese history and world development. The CPC's contribution and critical influence on the world is our future research work.

\section{Conclusions}

Under the strong leadership of the CPC, one hundred years is short, which enables China's most people liberated from the old society. The lift force of the Chinese people struggles. The CPC leads the whole nation, self-reliance, hard work, and hard fight, creates grand engineering construction, achieves the unprecedented magnificent epic and opens up a road to development suited to its national conditions. One hundred years of tremendous changes fully prove that the path taken by the Communist Party of China is bright and correct.

Over the past 100 years, the CPC has led the people in making grand achievements, and the CPC's contribution to the world will surely go down in history. Standing at the starting point of the second centenary, the CPC and the sons and daughters of China's 56 ethnic groups will firmly follow the path of national development, keep in mind the original aspiration of the country's mission, always be with the people, think what the people want, be anxious about what the people 
are sorrowful about, and make unremitting efforts to realize a prosperous China.

\section{Conflicts of Interest}

The author declares that there is no conflict of interests regarding the publication of this paper.

\section{References}

[1] Li, Z.J. (2021) The Birth and Development of the Communist Party of China Is a Historical Necessity. The Yangtze River Daily, 5, 1-3.

[2] Liu, L. (2019) Seek Happiness for the Chinese People and Rejuvenation for the Chinese Nation. Chuzhou Daily, 3, 1-2.

[3] Zhong, X.Z. and Luo, Z.G. (2021) Since the 19th National Congress, Xi Jinping's "People-Centered" Thought Basing on the Tradition and Making Innovations. Journal of Hubei University of Science and Technology, 41, 32-36.

[4] Dong, J.P. (2021) The CPC Is Showing Even Stronger Vigor and Vitality at Its 100th Anniversary. China Personnel News, 1, 1-3.

[5] Deng, C.D. (2021) Adherence to and Development of Marxism Is the Basic Premise of the Century-Long Journey to Prevail. People's BBS, the Academic Front, 12, 6-12.

[6] Huang, Y., Liu G., Li, H.F., Niu, Q. and Shi, L.H. (2021) Adhere to the "One Country, Two Systems" towards a National Revival. People's Daily, 5, 1-2.

[7] Chen, B.K. (2021) Only by Adhering to the "1992 Consensus" Can the Cross-Strait "Spring Blossom". People's Political Consultative Conference, 5, 1-2. 